\title{
LUT
}

University

\section{Deciphering Ownership of Family Business Groups}

Pihkala Timo, Goel Sanjay, Rautiainen Marita, Mukherjee Kajari, Ikävalko Markku

This is a Final draft version of a publication

published by Palgrave Macmillan, Cham

in The Family Business Group Phenomenon

DOI: 10.1007/978-3-319-98542-8_10

Copyright of the original publication: (c) The Author(s) 2019

Please cite the publication as follows:

Pihkala T., Goel S., Rautiainen M., Mukherjee K., Ikävalko M. (2019) Deciphering Ownership of Family Business Groups. In: Rautiainen M., Rosa P., Pihkala T., Parada M., Cruz A. (eds) The Family Business Group Phenomenon. Palgrave Macmillan, Cham

This is a parallel published version of an original publication. This version can differ from the original published article. 


\section{Deciphering Ownership of Family Business Groups}

Timo Pihkala, Sanjay Goel, Marita Rautiainen, Kajari Mukherjee and Markku Ikävalko

\section{Introduction}

For family business groups, ownership is a major defining issue. The concept of the family business group assumes underlying ownership relationships between the owners and the businesses owned, and the possible relationship between the owned businesses. Ownership is at the core of organizational structures; it forms the basis for wealth accumulation; and it is the intermediary substance in business transactions. By definition, the family business group is a result of two choices: their owners' choice of increasing their ownership positions beyond a single business, and their owners' choice of not integrating the acquired businesses into a single ownership position. These decisions have implications on the resulting bureaucratic costs of the organization as well as the costs of ownership. That is, locating the owned means of production within the different legal bodies suggests an interorganizational exchange that may lead to heightened transaction costs compared to exchange within the same organization. Similarly, owning a set of different organizations instead of one suggests increased costs of ownership. From some perspectives, family business groups may seem to be ineffective forms of ownership — and yet they are prevalent in every institutional and political context. Following this, we suggest that it is important to understand which advantages of ownership lead to the development of family business groups.

Family business groups’ ownership arrangements seem highly complex (Jaffe and Lane, 2004; Almeida and Wolfenzon, 2006). The complexity of ownership arises from three main sources: owners, businesses, and relationships between businesses. That is, new owners may join the family business group or old owners may leave the group; new businesses may be added into the family business group or old businesses may be excluded from the family business group; and finally, the ownership relations between the owned businesses may change within the group. The sources of ownership complexity in family business groups may result in different structures within the group. For example: 
- $\quad$ The businesses may be owned by the leading person of the family. This is often the case at the founding stage of the family business group (cf. Gersick et al., 1997). This ownership may be direct in each business, it may be channelled through a holding company, or a combination of these.

- $\quad$ Several family members may own businesses within the group not involving the whole family. This may lead to a situation where no single family member has shares in all the companies within the group, but the family as a whole owns shares in all the businesses in the group (Jaffe and Lane, 2004; Almeida and Wolfezon, 2006).

- Some or all of the businesses within the group may be owned through another company or companies. In these cases, the structure of ownership may form a pyramid with two or more levels. (cf. Almeida and Wolfezon, 2006) These structures may include one or several holding companies managing separate ownership arrangements.

- The whole group or separate businesses may involve non-family owners. Diversification decisions as well as business growth through mergers and acquisitions often lead to complex ownership relations.

- The businesses may have multiple series of shares with differential voting rights, thus leading to different positions of power and control.

- The owners may value the different businesses differently. That is, the different businesses in the group may have different objectives, resources, positions in the market, linkages to other businesses inside or outside the group and have different life cycles.

Ownership has been studied through by several theoretical and methodological treatments in philosophy, law, finance, economics and psychology throughout history (e.g. Grunebaum, 1987; Nordqvist, 2005), which implies that ownership is a multifaceted and influential phenomenon affecting different sides of human behaviour and human societies. One may say that ownership offers a specific set of unsolved challenges and paradoxes lying at the core of family business research. Even if the ownership structures of family business groups may be complex, they have been found to be flexible, loose, and persistent as well as tolerating rather well the pressures arising from the family dynamics (Mäkimattila et al., 2016). In this paper, we focus on those logics of ownership that lead to the 
development of family business groups. We analyse the ownership of family business groups from the legal, psychological, emotional and social viewpoints. The paper contributes to the research on family business groups in two key ways. First, it covers the different aspects of ownership related to family business groups. Second, it shows that the different types of ownership benefit family business group owners and support the further development of family business groups.

The paper is divided into three main sections. First, we highlight the concept of ownership especially from the ontological point of view. Then we present the benefits deriving from the legal ownership perspective. Third, we present the emotional and social elements related to ownership. Finally, the paper concludes with a discussion and suggestions for further research.

\section{About the concept of ownership}

To understand ownership in family business groups, we need to understand the ontological basis of ownership. Ontology of ownership here does not mean the nature and quality of the owner or the object being owned, but rather the nature of the connection between the owner and the object.

Everyone has the right of self-ownership, as each of us owns himself and his activities. This means the right to give away property either gratis or in exchange for something else. From the individual point of view, an owner has the right to use or not use his property as he sees fit, that is, any alteration in the physical constitution of the thing owned. When ownership is been proved, the owner can let it stay still or alter it in any manner whatsoever. According to the law, no authority can force an individual to give his or her ownership to another individual whom someone else designates.

Grunebaum (1987) stated that ownership is connected to the relationship between human beings and their actual surroundings - things and objects around them. Following this, ownership as a phenomenon and concept has various dimensions entailing at least legal, personal/psychological, and social and action/influence dimensions (Mattila and Ikävalko, 2003; Brundin, Samuelson, and Melin, 2005; Hall, 2005). 
Control and power are important elements in ownership. However, ownership hardly ever gives the owner the ultimate or transcendent power. Demsetz (1988) presented a concept called truncation of ownership rights, by which he referred to numerous limitations that western legal systems link to ownership rights. Emerson (1962) noted that power in general is a social phenomenon with persons or groups acting in power networks. These networks are tied together with multiple power-dependence relations where net power means an imbalance in dependence and power between different parties. We may assume that this state of being is also present in business ownership, at least on the basis of the popularity of agency theory and stewardship theory in management studies. Parts of the task that we may think belong to the owners may be carried out by someone else in an organization.

The concept of value reveals important aspects of the role of power and influence in the concept of ownership. Value is a very common concept in all branches of social sciences, and there are several, slightly different definitions of value and values (as, for example, reviewed by Meglino and Rawlin, 1998). When connected to an object, value means the worth of a thing: market price, purchasing power or estimated worth, but it also means the utilitarian importance of things (as noted by Dittmar, 1992).

From the utility point of view, control makes a significant difference. Control over a good adds significantly to its value for the subject who enjoys such control. The general value of certain objects, personally or socially valued, is not the same as objects that are at a subject's disposal from the subject's point of view. The existence of transactions is a certain kind of evidence. Transactions take place because the participating subjects perceive the value of objects differently, even when the monetary price paid and received are the same. This, along with the notion that a person can have possessive feelings towards an object (for example, Furby, 1978; Belk, 1988, Dittmar, 1992; Ahuvia, 2005; Mittal, 2006), gives ground for the notion of contextuality and situationality of ownership. The value of an object is an important driving force in the phenomenon of ownership, but we have no basis to assume that valuation of the objects would be universal and known beforehand. 


\section{Family business group as a set of legal ownership}

As a theoretical concept, ownership refers most often to jurisdictional meanings - to holding the rights to and being responsible for some specific, defined object. To a large extent, ownership has often been treated only as a legal status (e.g., Hall, 2005), and owners are regarded as acting according to the logic of 'economic man' (e.g., Jussila 2007). Most literature in business focuses primarily on the jurisdictional position and economic value of ownership that can be transacted away. With the legal perspective on family business group ownership, we are alerted to the need to acknowledge other, noneconomic factors that may affect the decision to own shares in more than one business. On the other hand, FBGs are a phenomena distinct from corporations holding more than one business, as the ownership may not be channelled through one holding company but the shares can be allocated for individual firms, not a business group as a whole. We suggest that beyond the legality, owning several businesses offers several benefits to owners that outweigh the costs of ownership from other perspectives as well.

\section{$<$ Insert table 9.1 about here $\rightarrow$}

\section{The benefits of controlling the business and its resources in family business groups}

A diversified business group can offer several benefits. For example, a business group may create value by allowing affiliated firms to allocate capital and managerial resources efficiently within the same group. The access to internal investment capital and risk sharing, for example a resource transfer from a well-performing business to a poorly performing business can be completed more efficiently. However, as the ownership wedge widens to increase the number of owners, the controlling owner's incentives to expropriate firm resources from other owners for private gain increase (Lemmon and Lins, 2003; Baek et al., 2004).

Having full control, the owners can make changes in the ownership of the businesses. Ownership changes can be used in the development of the business, developing relationships between family members, or providing family members with the ability to carry out their individual ventures 
(Rautiainen, 2012). As the business develops, there can be changes in the ownership positions - that is, start-ups, acquisitions, mergers, cooperative ventures, company splits, closings and sell-offs. These may be due to a variety of reasons, including spreading and containing business risks, recognizing entrepreneurial opportunities, consolidation to increase scale, or financing and investing by taking minority stakes. Diversification and growth are tied to the life cycle of the firm (Montgomery, 1994), and in the long run this development could shape the business into a business group. Ownership structures become complex through the integration of new owners and multiple businesses.

Protecting the family wealth and assets involves taking advantage of a diverse array of financial solutions tailored to the family's long-term needs. This includes the pooled personal resources that family members are willing to loan, contribute or share for the benefit of the family business. A substantial proportion of business founders have had previous experience in business ownership, and many own more than one firm (Carter and Ram, 2003). Previous experience provides greater knowledge of and insight into business ownership. Multiple business ownership may thus be seen as a mechanism for business growth (Scott and Rosa, 1996; Westhead et al., 2005). The more capital and economic and social resources owners have, the easier it is for them to start new businesses in the most profitable new business areas (Scott and Rosa, 1996). This makes the family business group very flexible and helps develop the longevity of the business group, as the owners also operate independently, and as the businesses are only loosely related to each other. The longevity of the FBG may satisfy the financial and non-financial objectives of the family business owners.

Legal control over the business provides the owner the ability to control the businesses in the group and to use the resources vested in the businesses rather freely. That is, family shareholders can dramatically influence the family business through their decisions regarding ownership. However, the business families do not exercise this right in full form. The attitudes and behaviours of family businesses may vary across generations, and the different owners may exhibit different interests. From a temporal business development perspective, for successful business-owning families, profit maximization may not be their first priority. Instead, they may adopt strategies that are more conducive to long-term growth. This may lead to lower profits from the business in the short-term. To secure their 
acceptable level of profits, family members may build personal diversified investment portfolios, tailored to their individual goals and circumstances.

The interplay between multiple social and financial factors is complex. There are behavioural factors, like the owners' need to be in control, that affect financial structure decision-making processes. The family firms' long-term perspective and the pride of their owners in the family history is one of the key reasons for their success. As long as the family is reasonably transparent about the tradeoffs it makes between short and long-term goals and economic and non-economic goals, it should be able to attract non-family investors who share more of these goals. As the goals of owners converge, the family business structure would avoid a rapid increase in complexity, and instead may benefit from leveraging resources of non-family owners.

\section{The benefits of including outside investors in the distinct businesses in the group}

Along with the growth of the family business group, its ownership structure is likely to grow more complex. The complexity of the ownership structure increases when the controlling family owns different proportions of shares in different companies. This can create severe agency problems and may have an effect on the firm's value (Kim and Yi, 2006).

Complex structures of FBGs make it difficult for outside investors to know the way resource transactions are conducted. Almeida and Wolfezon (2006) state that in a pyramidal ownership, business groups are used to manipulate the ownership structure of new businesses to maximize their financial wealth. Ownership structures grow complex through the integration of other businesses and ownership shared with several non-family stakeholders. When the family is successful, it can multiply its businesses and investments across the generations. As the family and business pass through various phases (Schwass et al., 2006; Gersick et al., 1999) and develop over time, value creation will obviously take place.

The agency and expropriation argument above reflects a static view of the relationship between family and non-family owners. First, it can be argued that non-family minority owners already factor in the risk of appropriation in their decision to invest in the firm. Therefore, their decision to invest may 
merely reflect the winning calculus of benefits from investing and profiting from the family ownership and management over the risk of having some of the profits expropriated. In this context, 'risk of expropriation' could be considered 'rent paid' to profit from the controlling family's entrepreneurial savvy, leadership, and managerial skills. Second, there are limits on the controlling family from expropriation as well. If the family develops a reputation for expropriating from minority investors, stakes in the family business would be severely discounted in the market, and the family business would not be able to raise money commensurate to the intrinsic value of the business. This suggests that expropriation would not be a costless luxury for the controlling family, who may instead unlock more value by developing a reputation as smart and savvy owners, managers and stewards of capital.

\section{The benefit of operating on the levels of collective ownership and individual ownership}

Family business groups often include businesses that are related to personal interests of one or a few family members rather than the collective interest of the family. While this characteristic may be one factor creating the flexibility and longevity of the family business groups, they also highlight the vagueness of the ownership structure. As a family business develops and diversifies and ownership is shared with several family members, the core business may be divested or sold, or family members may inherit their own fortunes and go their separate ways (Jaffe and Lane, 2004).

The family's original fortune is usually created by a single founder. Over generations, the fortune is divided among a growing pool of heirs and relatives. Each generation of leadership can bring to the business new strategic ideas that build on underlying, long-held competencies developed for earlier strategies (Ward, 1997). Issues of ownership, representation, management and financial returns are subjected to family and personal development considerations (Jaffe and Lane, 2004). It is difficult to keep the fortune unified. Collaboration, conflict resolution and shared governance are difficult by nature.

Family-influenced transgenerational wealth creation has been under investigation for some time now (Hall et al., 2001; Habbershon and Pistrui, 2002; Kellermanns and Eddleston, 2006). Habbershon and Pistrui (2002) identified the family ownership group to be the unit of analysis to explore 
transgenerational wealth creation in the family. They conclude that when the family has an investor mind-set they better fulfil family's commitment to transgenerational wealth. Doing this, family businesses face inherent and natural forces to become more complex over time and generations. Complexity arises from the number of owners, goal heterogeneity among owners, induction of new adult members into the family, and variation in socialization practices of new adult members, among other characteristics of family businesses.

Family business succession, that is, the intergenerational transfer, is the major element in family business and family wealth accumulation. Families relinquish ownership slowly, and although the group of owners grows, control of the family businesses can remain strong even after several generations (Anderson and Reeb, 2003; Gersick et al., 1997; Ehrhardt et al., 2005). Family business succession is the process through which a change in ownership most frequently occurs. It is a long-term process with multiple activities (Sharma et al., 2003) and comprises legal, psychological and social aspects.

Inheritance laws play an active role in determining the prevalence and persistence of family firms in different countries (Colli, 2003). In many countries, family business succession also means that there will be a considerable inheritance tax, which plays an important role in understanding the impact on the development of the family business. Inheritance tax laws act as crucial constraints that foster intergenerational transfer of ownership in family firms (Sund and Bjuggren, 2008). The wealthier an individual is, the more likely it is that a bequest will be left.

An equal subdivision among heirs shapes the strategies of succession in family firms, and hence their governance and performance. The prime objectives of many family businesses are 'to maintain control and pass on a secure and sound business to the next generation' (Errington, 2002). Karlsson Stider (2000) acknowledges that the members of the family not only perceive their company ownership as an economic inheritance, but also a social, cultural and symbolic inheritance from their ancestors. The inheritance can take financial (e.g. money), social (e.g. relations) and symbolic (e.g. status) forms. In a family business, tenures are longer; and due to their centrality of position in the family and the firm, founders exert considerable influence on culture and performance. Family businesses face challenges due to the duality or multiplicity of roles (that is, as father, husband, and president of the company), and problems can occur when one family member acts out a role inappropriate for the situation (Johnston, 
2007). The inheritance can be viewed as a relationship. A more complex relationship to the company implies that the owner's assessment of the company's development and strategies are not solely based on economic performance. Long-lived family businesses face particular challenges when both the family and the business grow older and larger. The nature and expectations of family shareholders change substantially in different generations (De Visscher et al., 1995). The owners of a family business often have their personal wealth concentrated in the business, ownership is usually shared with other family members, and shareholders are usually shareholders for life.

\section{Emotional and social benefits of owning a family business group}

Family businesses offer an unusual social phenomenon, as the family and business are overlapping. In the family business, the value of ownership is not only composed of its financial worth and private benefits; emotional components have a significant impact on valuation (Astrachan and Jaskiewicz, 2008). While the emotional and social aspects mostly emanate from the legal relationship, they cause a set of consequences that makes ownership more complicated and difficult to manage, beyond the bare question of who owns the shares. In studies of family business and ownership, ownership contains soft dimensions such as psychological, social, socio-symbolic and cultural (Brundin et al., 2005; Nordqvist, 2005; Ikävalko et al., 2010). Within a family firm, the emotional attachment to ownership may detract from the firm's focus on economic goals. Thus, a typical family firm violates almost all the underlying assumptions of traditional governance theories (Mustakallio et al., 2002).

To gain an encompassing perspective on the issue, we analyse what emotional and social benefits are related to owning several businesses. We suggest that from the emotional and social perspective, owning several businesses offers several benefits that outweigh the costs of ownership.

\footnotetext{
$<$ Insert table 9.2 about here $\rightarrow$
} 


\section{The benefits of owning family business group on personal goals}

The collection of several businesses in a business group provides the owners with opportunities to follow self-deserving interests. In family business groups, this may lead to complexities, as each owner may want to fulfil his or her own personal interests through their ownership. Among the owners, it is likely that there is a variation in personal interests. Owners may decide to stay with the group depending on the extent of conflict and their idiosyncratic cost-benefit calculus of being co-owners with other owners of the group. An element of this calculus could be the owner's 'psychological ownership' in the group. The concept of psychological ownership refers to a situation where a person feels that something is 'mine', and emerges as a result of a set of processes (Pierce et al., 2001; 2003). The processes concern the development of three layers of knowledge: the cognitive (to know the subject), the power (to control the subject) and the personal investment and target of work (to invest in the subject). In this sense, depending on the owners' perceptions of those aspects, the owners may have differential emotional feelings for their separate businesses. The level of psychological ownership, on the other hand, would determine the owner's level of interest and expectations for the businesses.

Family business groups provide a way to growth and wealth accumulation. The accumulation of family wealth requires an entrepreneur who is growth- and profit-oriented. Habitual entrepreneurs, that is, portfolio and serial entrepreneurs, have been observed to be more growth-oriented compared to novice business owners (Ucbasaran et al., 2001); the growth is designed through the group structure to facilitate capitalization. Sometimes these growth patterns may be better explained with the achievement motive rather than growth or wealth accumulation. Del Giudice (2017) suggested that the notions of growth and development may be deceiving if they are interpreted as being the same thing. Development is the formation of a solid prospect for future profitability connected to competencies and efficiency synergies within the firm, whereas growth constitutes the progressive enlargement of the size of the firm and does not ensure development (Del Giudice, 2017). In these cases, growth and wealth accumulation are more means to reach the achievement than vice versa. From this perspective, the personal interests between growth and wealth retention do not always coincide. 
According to Hoy and Verser (1994, p.17), in family business 'the growth goals of the founder may be in direct conflict with the desire for wealth accumulation by the family'. This could mean that the business group structure has not been developed to serve the interests of family wealth generation. Economic theory posits (Behrman et al., 2012) that individuals maximize expected lifetime utility using economic information to build retirement assets over their working lives. People who do not understand their financial environment are less likely to accumulate wealth (Behrman et al., 2012).

Much saving is undertaken with no thought of bequests in mind; people accumulate property for a variety of reasons - future security and enjoyment; the power that wealth confers; inertia - the sheer inability to spend their wealth; the desire to manage a large business; the posthumous glory of dying rich; and many others which are unaffected by death duty considerations. (Sandford, 1984, p. 226).

Among the businesses in the business group, there may be businesses that are not fulfilling the goals of profit making or growth but are there because the owners want to own them for some other reasons. These reasons may include different leisure purposes or personal interests.

\section{The benefits of family business group ownership on family cohesion and business continuity}

Ownership of a family business group may support the development of bonds between family members. A family consists of individual family members who, through their existence and social action, jointly construct the family. The family businesses are owned together by several family members and decisions should be made collectively, while at the same time, the members involved are individuals who make their own decisions. To overcome this paradoxical situation, family members may emphasize family cohesion and continuity. The discussions, agreements, division of work and interests as well as experience of joint benefit are elements that support the feeling of togetherness. In family business groups that need constant decision-making about business objectives, business transitions, systematic discussions about the share ownership, and the benefit of the family, the family members' interaction is likely to stay high and thereby create cohesion. The high cohesion among the family is closely related to the feeling of collective ownership of the businesses. 
From the collective ownership point of view, the family should be thought of as a constantly changing multigenerational system where members are connected to each other. Stein (1976) claims that the essential point in collective ownership is that the collective must exercise its ownership rights as a unit; individual members of the collective are not themselves owners. Individuals are members of multiple social groups with a collective identity. A collective identity is the cognitive, normative and emotional connection experienced by members of a social group because of their perceived common status with other members of the social group. Collective identities emerge out of social interactions and communications between members of the social group (White, 1991).

The family involvement and family members' intentions to pursue particular goals affect in various ways firm strategies, behaviour and performance. Such intentions can lead to behaviour oriented toward preserving the family wealth at the expense of business development. Consequently, family firm behaviour is distinct from non-family firms, as the emotional attachment of ownership is seen as equally important as financial performance (Thomas, 2002). Family owners and managers are more likely to form strong personal identification with their organization and view the firm as an ongoing 'social enterprise' to be passed on to future generations (Schneper et al., 2008). The outcome of a high level of ownership feelings creates a strong dedication to the family business that is seen as a major advantage when compared to non-family business (Bernhard and O’Driscoll, 2011).

Owning a business together does not automatically create cohesion. Cocutz (1953) says that making an economic decision is always an individual and private matter, and people cannot make decisions together; rather, people make decisions in their minds and then compare their individual decisions to see if they agree or disagree. Individuals who own property together are entitled as owners to make decisions, and these decisions often conflict with each other. Solving conflicts requires the establishment of rules regarding equal ownership or equality of individual decisions in relation to each other, which will establish which one of the various decisions will be enforced. The decisions are not made by the majority as a group, but by each individual of the majority (Cocutz, 1953).

Due to high cohesion within the family, family members may show loyalty to the family's objectives at the cost of personal freedom of choice. In this sense, the family, as a collective, may in fact prevent some individual entrepreneurial intentions and ventures, should those ventures not serve 
the family agenda. Although the family's prime objective could be to maintain control and ownership of the business at the group level, individual members of the family might have their own interests in and ideas about their ownership. This does not necessarily mean that they want to leave the family business; they can still be in an owner's role when playing the role of investor (Aronoff and Ward, 1996), spreading risks or investing in different opportunities. If the individually owned businesses can be included within the family business group structure, it will support maintaining of the family cohesion.

An individual's interpersonal crisis or dissent with the family can also affect family cohesion. Conflicts are inevitable, so disagreements and an interfamilial crisis can spark problems that result in a change in ownership, for example task, process, and relationship conflicts (Jehn et al., 2001). Disagreements over management or strategy are common in large families with several family members. The individual family member is simultaneously a person weighing his or her options as well as a member of the family. An owner's actions and demands affect other stakeholders in the family business (Ward, 2001); people regularly join and leave the family system and move from one dimension of the business to another.

Compared to the other business systems, family businesses have the added complexity of family members working closely with other family members. For securing continuity, succession is the process through which a change in ownership most frequently occurs. It is a long-term process with multiple activities and interactions (Sharma et al., 2003); and with family business groups, the process is even more challenging and time-consuming. As an on-going relationship, the family forms an arena for carrying over the inherent and tacit knowledge of the businesses and their operations. This takes place through the internal culture of the family, its way of talking about business, entrepreneurship, new ventures, competition and its commitment to the long-term development of the company (Johannisson and Huse, 2000). The family culture and values inspire strong feelings and can be powerful drivers of change in ownership (Hall, Melin, and Nordqvist, 2001), since the family typically has a set of shared traditions and values rooted in the family history (Chrisman et al., 2003; Habberson et al., 2003). As the family and business pass through various phases (Schwass et al., 2006; Gersick et al., 1999) and develop over time and across generations, value creation will obviously take place. Although the group 
of owners grows, the structure of ownership can remain static for generations (Andersson and Reeb, 2003; Gersick et al., 1997).

\section{Social benefits of owning a family business group}

The social benefits of ownership, that is, the status in the community and membership in specific power structures of external institutions, has been covered only marginally in the family business group literature. However, it is evident that affiliation to a family business group creates social benefits that affect the family members, the group and separate businesses within the group. These effects are reflected as social status and social recognition of the business and its owners.

Family business groups form a large social entity with several cooperating networks. Stakeholders and interest groups create closer ties with the owners and develop a social interaction with both retirees and succeeding generations (Nordqvist, 2005). Social ownership takes place during social interaction, includes negotiations regarding ownership, and results in mutual agreements about ownership (Brundin et al., 2005). More formal and informal interactions may clarify issues around ownership and help each family member be reassured of the security of his or her ownership, as well as acknowledge ownership of others. In social identity theory, it is widely recognized that belonging to a certain group shapes individuals' definitions of themselves and their feelings of well-being and selfworth (Sedikides and Brewer, 2001; Tyler and Blader, 2003). In other words, stakeholders in a family business group form a social identity that is recognized and identified with the group. In addition, outsiders to the group have a possibility to recognise this social identity and interact with it. As a result, the groups' identity implications for the stakeholder within the family business group is the social recognition, which could become a larger part of their personal identities.

Together with social recognition, family affiliation creates a certain status for its owner. Social status itself is a multidimensional concept which has been extensively studied within the fields of sociology and social psychology (Piazza and Castellucci, 2013). Status is defined as a relationship between social groups (Ridgeway and Ericson, 2002) as well as a hierarchical relationship between individuals (Skvoretz and Fararo, 1996). Social status in the community and membership in specific 
power structures of external institutions is a signal that an individual or an organization is part of a welldefined social hierarchy. Status confers a respected standing that offers a variety of advantages; for example, an individual is considered a better performer (Lynn et al., 2009). This is particularly apparent in the fact that an entrepreneur with many companies is considered capable of managing complex structures and situations. For this reason, ownership of a family business group may support 'respect, admiration, and importance in the eyes of others' (Gregg, Mahadevan, \& Sedikides, 2018). While it is unlikely that social status would be the main motivation for entrepreneurs to grow their businesses, it seems plausible that along with the achievement motive, gaining social status would support the development of family business groups.

\section{Managing the complexity of the ownership of family business groups}

When ownership is dispersed, control over the business becomes harder to exercise (Schulze, Lubatkin, and Dino, 2003). The question of how the family manages the diverse ownership group (Thomas, 2002) still needs further examination, particularly in multigenerational family businesses where the original business has diversified into several companies, and ownership between business and owners is complex. If family businesses cannot manage the complexity, the family business dissolves and changes ownership, with the original family owners receiving an assessed economic value for the business. The long-term success of family businesses is achieved by meeting the needs of each generation to reaffirm their commitment as responsible owners and proactively anticipating the future needs of the family and the business (Schwass, 2008). Family businesses have a long time horizon, so financial capital management has a long-term focus. Family businesses manage complexity in three ways:

1. Soft and malleable structures that keep the complexity manageable by reducing its level. These structures include family cohesion and harmony, mutual trust among family members, active socialization of non-family additions to the family, and active narrative construction and reconstruction about the family and family business. 
2. Hard structures that increase the complexity of internal structures to be commensurate to the level of complexity. These structures include formal family governance structures, formal procedures that establish procedural fairness and justice, and formal role differentiation among family members and owners. The rules may include limiting the number of family owners by a variety of means. These hard structures limit the discretion of individual owners, but by specifying a priori the rights and obligations of owners as well as formal procedures to address any conflicts or initiate changes in any rules, they aim to provide transparency and procedural fairness to all owners.

3. Idiosyncratic, 'genetic' resources within the family business. These sources are highly family-specific and random. Examples would be a family member or leader with extraordinary capabilities (for example, a mercurial leader, or a great negotiator or mediator), who can resolve the complexity for an extended period via his or her personality, organic development and snowballing of complexity-reducing routines (for example, the family's idiosyncratic customs or rituals).

There is a path dependency to some extent in the degree to which the family makes progress in establishing and exploiting these complexity-management strategies. The early decisions by the founder and the founding conditions have a significant influence on the degree to which these strategies can be adopted in subsequent generations.

Among the decisions of the founder, a key element is the timing of 'intentionality' when a founders begins to view the business that they founded as a family business that could be managed as a family asset for the long-term. Once the founders begin to see their business as a family business, then they may begin to make decisions about preserving and unlocking the value of the business over a longer time horizon. These decisions could relate to whether the ownership would be shared among the next generation, or would it be concentrated in one or a small number of next-generation potential owners.

The hard and soft structures are likely to be both complements and substitutes for each other. Hard structures like family councils can substitute the absence of family cohesion to some extent, for example. However, both structures may also complement the efficacy of each structure to manage 
complexity. A corollary of this aspect is that care must be taken by family businesses to not impose excessively hard, formal structures on the family business. The more the family business tries to resolve complexity by hard structures alone, the more likely the business may be 'sanitized' of family influence, and the family business may begin to resemble a non-family business. A tangible indication of this could be when family members become disinterested owners or completely divest their ownership of the family business.

What should be the goal of the family business with respect to increasing complexity as the family business grows in size and age? We suggest that the goal of a family business should not be to eliminate or 'tightly' control complexity. Rather, the goal should be to manage complexity to the point that it does not overwhelm and destroy the family business. Indeed, the complexity of the family business could also be a unique fount of entrepreneurial ideas and entrepreneurial ventures that may connect the family across generations by combining heritage and innovation.

Dealing with complexity by eliminating or tamping it down may lead to stagnation of the family business by limiting its focus to current operations - in other words, reducing business complexity as well as family complexity. A tightly defined business and family boundary may indeed reduce the complexity of the family business, but it may make the family complacent. This could be one reason why many family businesses remain in a single line of business and why they are found in industries where returns for innovation are relatively low, for example restaurants, shipping and agriculture. Family businesses that adroitly manage complexity allow themselves the possibility to harness multiple business ideas and develop a portfolio of companies that match the family's growing complexity.

\section{Future directions for research}

Our discussion on ownership and its value from different perspectives offers several fruitful areas for future research.

One intriguing area of research would be to trace the evolution of FBGs over a long period of time. Based on our exposition above, we believe that FBG evolution would show a wider variety of trajectories. In particular, FBG evolution would reflect the idiosyncratic factors from the family domain. 
At the structural level, the sheer size of the family and the way the family grows (for example deaths, marriages, divorces, remarriages, number of progeny and their spacing, etc.) would have an effect on how the FBG evolves. But a deeper understanding of family history, family culture and family members in consonance with the context surrounding the family would yield even more nuanced and useful insights into the development of the FBG structure. We believe more studies from a business history perspective could provide a rich and holistic understanding, not just about the development of the FBG structure, but also a more nuanced understanding of specific entrepreneurial and entropic decisions and events that were associated with the FBG. In particular, it may lead to a finer grained contingent understanding of the use of different kinds of pyramidal structures and specific behaviours such as tunnelling and expropriation from non-family minority investors.

Our exposition on different perspectives on collective (family) and individual ownership provides a good background to understanding the evolution of FBG structures. For example, FBGs may develop organically to accommodate family members' interests and ownership rather than via a rational analysis of environmental opportunities. Some businesses may be added to the FBG to earn or acknowledge a family member's emotional ownership in the family business. The resultant FBG structure may be an amalgam of various ownership perspectives, which themselves could be a function of the family's unique history and circumstances and their interaction with their institutional environment. Empirical research is needed, especially one that is agnostic with respect to a theoretical perspective (that is, not presuming agency or stewardship orientation) and is more sensitive to the family context nested within an institutional context and which may ultimately lead to a rich perspective.

One outcome of acknowledging the emotional aspects of ownership at the individual level, while also viewing the family as a group with collective ownership, is that it may explain the economic irrationality and randomness in FBG evolution and development. The FBG development may include decisions that may have been taken to maintain members' emotional ownership in the FBG by supporting the members' 'pet' businesses and to reinforce the collective ownership of the family in the FBG. These personally championed businesses within family business groups deserve a special focushow do they affect the development of FBGs? This also suggests that FBGs over the years would reflect certain key characteristics of the owning family, making them more idiosyncratic and intractable 
through the lens of pure economic rationality. The existence of 'pet' businesses that generate significant emotional benefits to their owners may also make them 'sticky' in the FBG, harder to rationalize and dispose of even if the businesses are a drag on the group's economic performance. Other family members who may not be as emotionally invested in these businesses may try to manoeuvre to contain the risk of the business in other ways — for example, by bringing in outside investors who may be able to impose financial discipline on the business that other family members were uncomfortable imposing themselves. Again, deeper studies that trace the dynamic of FBG transformation through the lens of ownership benefits and ownership rights of the family and family members may yield interesting insights into how ownership issues lead to FBG evolution-and in particular, the 'equilibrium' conditions in this evolution.

Based on our exposition on different kind of ownerships (that is, legal and emotional) that family members may bring to bear in their decisions, a fruitful area of research would be the interaction of these different kinds of ownership in their decisions about the extent to which they wish to be associated with the family business and in what capacity. Furthermore, how do these ownerships interact to create a balance of rights versus responsibilities among family members?

Other questions that relate to the relationships between different kinds of ownership could relate to whether they develop in consonance, and whether some kinds of ownership is earned rather than inherited. It would appear that emotional ownership could develop from a very young age, reinforced by critical symbolic events, and these may then prepare members to expect or accept legal ownership later. But if the members have no emotional ownership and merely inherit legal ownership later, does it lead them to value it less? In other words, does the way they achieve ownership (earned versus inherited) affect the value they derive from their ownership? Among the personal values in ownership, the social status of owners may be related to the ownership—-how does it transfer to the next generation? And do those family members who do not own the business also gain the social status?

We can also take a step back and study the substantive and symbolic actions in the family, the leadership behaviour that leads to the sharing of a common FBG identity among individual family members, and the contingencies that lead to its formation or disintegration. Families grow naturally as separate but related branches, and it is likely that well-run FBGs creatively and consciously adopt 
several mechanisms to keep the branches functionally cohesive. These could include not only developing rules about ownership, but also specific cultural practices that are hardwired in family functioning.

\section{Conclusions}

An ownership perspective opens both new challenges and new opportunities. In this paper, we have suggested that family business ownership needs to create benefits that overcome the transaction costs and ownership costs emerging from the family business group structure. We separated the effects of ownership into two main categories: the legal effects and the emotional effects.

In terms of legal ownership, the control over the business and its resources is in a central role. It means freedom to operate the businesses and claims on their resources, to append new businesses to the FBG, to organize their relationships between the separate businesses and to exit from the businesses at will. The family business group allocates resources and shares risks within the group (Khanna and Yafeh, 2007). The group structure enables resource allocation within the group; that is, stable and productive companies can assist those companies that are less successful. Intragroup resource allocation can exacerbate the agency problems, as there is a divergence between control and ownership (Claessens et al., 2000), so controlling shareholders can transfer resources out of the companies for their own benefit (Johnson et al., 2000). At the same time, legal ownership provides the owner with the power to affect other people's positions. In essence, the owner of a business group can invite family members to own the businesses, and he or she can also invite outsiders into the businesses. By doing so, the owners can benefit financially and increase the growth possibilities of the business group.

The emotional aspects related to ownership create a number of benefits that owners may seek to gain when developing their family business groups. First, ownership of a family business group may serve the owners' self-deserving interests. These interests may include the need for achievement motive, growth aspirations or a desire to become wealthy. Seeking these benefits, it is possible that different conflicts of interest arise between the owners. Second, ownership of family business group may have a positive effect on family cohesion and togetherness. Managing the complex structure needs family 
members' constant interaction that supports the feelings of joint benefit and mission. On the other hand, the FBG structure may incorporate different personal business interests of the family members, and thus suffer from the negative effects of highly individualized entrepreneurial ventures only loosely tied to the FBG. Third, ownership of the family business group affects the social recognition and status of its owners.

Our deliberation suggests that ownership along with its multiple effects may play a more vital role in explaining the development of family business groups than has been previously thought. While the founding and initial growth of the family business may still reflect entrepreneurship as a dominant force, ownership issues increase in importance in explaining its sustainability and longevity. Often the founder (that is, the portfolio entrepreneur) builds the group in the very early stage. When it comes time for the first succession, the business may not only have grown, but there also may be an impressive number of companies in the entrepreneur's possession. Family members may be interested in continuing the family business in some other sector, for example, an industry that is more familiar to the next generation because of their interests. In such cases, the family may own several firms as a collective and act as entrepreneurs, investors, and managers. Other family members and other family businesses may have an influence on the outcome even if they are not legal owners, driven by their acceptance of other forms of ownership.

\section{References}

Ahuvia, A. C. 2005. Beyond the Extended Self: Loved Objects and Consumers’ Identity Narratives. Journal of Consumer Research. 32(1): 171 - 184.

Almeida, H. and D. Wolfenzon (2006). 'A Theory of Pyramidal Ownership and Family Business Groups.’ The Journal of Finance, 61(6), 2637-2680.

Anderson, R.C. and D.M. Reeb (2003). ‘Founding Family Ownership and Firm Performance: Evidence from the S\&P 500.' Journal of Finance, 58, 1301-1328.

Aronoff, Craig E. and John L. Ward. (1996). Family Business Governance: Maximizing Family and Business Potential. New York: Palgrave Macmillan, 2010. Print. 
Astrachan, Joseph H and Peter Jaskiewicz. 2008. Emotional Returns and Emotional Costs in Privately Held Family Businesses: Advancing Traditional Business Valuation. Family Business Review 21(2): $139-149$.

Baek, J., J. Kang, and K. S. Park. 2004. Corporate governance and firm value: Evidence from the Korean financial crisis. Journal of Financial Economics 71 (2): 205-415.

Behrman, J.R., Mitchell, O.S., Soo, C.K. and Bravo, D. (2012). How Financial Literacy Affects Household Wealth Accumulation. American Economic Review: Papers \& Proceedings, 102(3): $300-304$.

Belk, R.W. 1988. Possessions and the extended self. Journal of Consumer Research. 15: 139 - 168.

Bernhard, Fabian and Michael P O’Driscoll. 2011. Psychological Ownership in Small Family-Owned Businesses: Leadership Style and Nonfamily-Employees`Work Attitudes and Behaviors. Group \& Organization Management. 36(3): 345 - 384.

Brundin, Elin, Samuelsson, E.F., and Leif Melin (2005). 'The family ownership logic - Core characteristics of family controlled businesses.' Paper presented at the Family business Network 16th World Conference, Brussels, Septemper.

Carter, S. and M. Ram (2003).’Reasessing portfolio entrepreneurship.' Small Business Economics, 21(4), 371-80.

Chrisman, J.J., Chua, J.H., and Shaker A. Zahra (2003). 'Crating Wealth in Family Firms through Managing Resources: Comments and Extensions.' Entrepreneurship Theory \& Practise, 27(4), 359-365.

Claessens, Stijn, Simeon Djankov, Joseph P H Fan, and Larry H P Lang. 1999. The separation of ownership and control in East Asian corporations. Journal of Financial Economics 58: 81 112.

Cocutz, J.T. (1953). ‘Does Social Ownership Have Any Meaning?’ Ethics, 64(1), $46-50$ Published by: The University of Chicago Press.

Colli, A. (2003). ‘The History of Family Business.’ Economic History Society, Cambridge University Press, Cambridge, UK. 
Danes, Sharon M, Kathryn Stafford, George Haynes, and Sayali S Amarapurkar. (2009). Family Capital of Family Firms, Bridging Human, Social, and Financial Capital. Family Business Review, 22(3): $199-215$.

Del Giudice, Manolio. 2017. From Family Businesses to Business Groups. In: Understanding FamilyOwned Business Groups. Palgrave Studies in Democracy, Innovation, and Entrepreneurship for Growth. Palgrave Macmillan, Cham

Demsetz, H. 1988. Ownership, Control, and the Firm. The Organization of Economic Activity. 1, Oxford: Basil Blackwell.

Dittmar, H. 1992. The social psychology of material possessions: To have is not to be. New York: St. Martin's Press.

Ehrhardt, O., Nowak, E., and F-M. Weber (2005). 'Running in the Family` The Evolution of Ownership, Control, and Performance in German Family-owned Firms 1903-2003.' Working paper, University of Berlin, Germany.

Emerson, R.M. 1962. Power-Dependence Relations. American Sociological Review. 27(1): 31 - 41.

Errington, A.J. and M. Lobley (2002). 'Handing over the reins; a comparative study of intergenerational farm transfers in England, France, Canada and USA.' Paper presented at the meeting of the Agricultural Economics Society, Aberystwyth, UK.

Furby, L. 1980. The Origins and early development of possessive behaviour. Political Psychology, 2(1): $30-42$.

Gersick, K.E., Lansberg, I., Desjardins, M., and B. Dunn (1999). 'Stages and transitions: Managing change in the family business.' Family Business Review, 12(4), 287-297.

Gersick, K.E., Davis, J.A., Hampton, M.M., and I. Lansberg, (1997). 'Generation to Generation, Life cycles of the family business.' Boston, MA: Haward Business School press.

Gregg, Aiden P., Nikhila Mahadevan, \& Constantine Sedikides, (2018). Taking the high ground: the impact of social status on the derogation of ideological opponents. Social Cognition 36, 1, 4377.

Grunebaum, J. O. (1987). ‘Private Ownership.’ Routledge \& Kegan Paul, London. 
Habbershon, T., Williams, M., and I.C. MacMillan (2003). 'A unified systems perspective of family firm performance.' Journal of Business Venturing, 18(5), 451-465.

Habbershon, T.G. and Pistrui, J. (2002). Enterprising families domain: Family-influenced ownership groups in pursuit of transgenerational wealth. Family Business Review 15(3): 223-237.

Hall, A. Melin, L. and Nordqvist, M. (2001). Entrepreneurship as radical change in the family business: Exploring the role of cultural patterns. Family Business Review 14(3): 193-208.

Hall, A. (2005). 'Beyond the legal: psychological ownership and responsibility in the family business', Paper presented at the FBN 16th Annual World Conference, Brussels, Belgium, September, 2005.

Hoy, Frank and Trudy G Verser. 1994. Emerging Business, Emerging Field: Entrepreneurship and the Family Firm. Entrepreneurship Theory and Practice. 19(1): 9 - 23.

Ikävalko, Markku, Timo Pihkala and Sascha Kraus (2010). The role of owner-managers’ psychological ownership in SME strategic behavior. Journal of Small Business and Entrepreneurship. 23 (3), 461-480.

Jaffe, D.T. and S.H. Lane (2004). 'Sustaining a Family Dynasty: Key Issues Facing Complex multigenerational Business- and Investment-Owning Families.' Family Business Review, 17(1), 81-98.

Jehn, K.A. and E.A. Mannix (2001). 'The dynamic nature of conflict: A longitudinal stydy of intragroup conflict and group performance.’ Academy of Management Journal, 44(2), 238-251.

Johannisson, B. and M. Huse (2000). 'Recruiting outside board members in the small family business: an ideological challenge.’ Entrepreneurship and Regional Development, 12(4), 353-378,

Johnson, Simon, Rafael La Porta, Florencio Lopez-de-Silanes, and Andrei Shleifer. 2000. Tunnelling. American Economic Review 90(2): 22-27.

Johnston, S.E. (2007). 'The Family Business: Statistics, Profiles and Peculiarities.' Business Management Dept.-De La Salle University.

Jussila, Iiro. 2007. Omistajuus asiakasomisteisissa osuuskunnissa [eng. Ownership in Customer-owned Cooperatives (Doctoral Dissertation)]. Acta Universitatis Lappeenrantaensis 271. ISBN 978-952-214-4089. 
Karlsson Stider, A. (2002). 'Familjen \& Firman.’ Ph.D. thesis, EFI. The Economic Research Institute at the Stockholm School of Economics. Stockholm.

Khanna, T., Yafeh, Y., (2007). Business groups in emerging markets: paragons or parasites? Journal of Economic Literature, 45(2), 331-372.

Kim, J-B. and Yi, C.H. (2006). Ownership Structure, Business Group Affiliation, Listing Status, and Earnings Management: Evidence from Korea. Contemporary Accounting Research, 23(2): 427 $-464$.

Kellermanns, F. W. and Eddleston, K. (2006). Corporate entrepreneurship in family firms: A family perspective. Entrepreneurship Theory and Practice, 30(6): 809-830.

Lemmon, M. L., and K. V. Lins. 2003. Ownership structure, corporate governance, and firm value: Evidence from the East Asian financial crisis. The Journal of Finance 58 (4): 1445-68.

Lynn, F. B., Podolny, J. M., Tao, L. 2009. A sociological (de)construction of the relationship between status and quality. American Journal of Sociology, 115: 755-804.

Mattila, J. and M. Ikävalko (2003). 'Participative strategy process in a professional organization and the concept of psychological ownership.' Paper presented in NORDFEK conference, Island.

Mittal, B. 2006. I, me and mine - how products become consumers' extended selves. Journal of Consumer Behaviour. 5(5): 550 - 562.

Meglino, B. M., and Ravlin, E. C. 1998. Individual values in organizations: Concepts, controversies, and research. Journal of Management, 24: 351-389.

Montgomery, C.A. (1994). 'Corporate diversification.' Journal of Economic Perspectives 8 (3), 163 178

Mustakallio, M., Autio, E., and S. Zahra (2002). 'Relational and contractual governance in family firms: Effects on strategic decision making.' Family Business Review, 15(3), 205-223.

Nordqvist, M. (2005). 'Understanding the Role of Ownership in Strategizing: A Study of Family Firms.' JIBS Dissertation Series, No. 29. Jönköping: Jönköping International Business School

Piazza, Alessandro and Fabrizio Castellucci. 2013. Status in Organization and Management Theory. Journal of Management. 40(1): 287 - 315. 
Pierce, J. L., Kostova, T., and K.T. Dirks (2003). 'The State of Psychological Ownerhip: Integrating and Extending A Century of Research’ A Review of General Psychology, 7(1), 84-107.

Pierce, J.L., Kostova, T., and K.T. Dirks (2001). 'Toward a Theory of Psychological Ownership In Organizations.’ Academy of Management Review, 26(2), 298-310.

Rautiainen, M. (2012). Dynamic Ownership in Family Business Systems - A Portfolio Approach. Acta universitatis Lappeenrantaensis 485, Lappeenranta University of Technology. (Dissertation).

Rautiainen, M., Pihkala, T., and M. Ikävalko (2010). 'Family business in family ownership portfolios.' International Journal of Entrepreneurial Venturing 1(4), 398-413.

Rautiainen, M., Pihkala, T., and M. Ikävalko (2007). 'Ownership matrix - Families as actors for portfolio entrepreneurship.' Paper presented at the $19^{\text {th }}$ Nordic Academy of Management Conference, Bergen, NorwaySandford, C. (1984). Economics of Public Finance, Third ed., Oxford: Pergamon Press.

Ridgeway, C. L., Erickson, K. G. 2000. Creating and spreading status beliefs. American Journal of Sociology, 106: 579-615.

Sandford, C. 1984. Economics of Public Finance, Third ed., Oxford: Pergamon Press.

Schneper, W.D., Celo, S., and N.K. Jain (2008). 'Agents, Altruism, and Corporate Governance: The Impact of Family Ownership on Non-Executive Compensation and Training.' Proceedings of ASBBS, 15(1).

Schwass, J. (2008). 'Dealing with the Complexity of Family Business; Strategies for long-term success.’ IMD, Lausanne, Switzerland.

Schwass, J. and A.A. Diversé (2006). 'Private Wealth: Origin and Destination from Entrepreneurship to Family Offices.’ IMD, Perspective for Managers No. 140, 1-4.

Scott, M. and P. Rosa (1996). 'Has Firm Level Analysis Reached its Limits? Time for a Rethink' International Small Business Journal, 14(4), 81-89.

Schulze, W.S., Lubatkin, M.H., and R.N. Dino (2003). 'Exploring the agency consequences of ownership dispersion among the directors of private family firms.' Academy of Management Journal, 46, 179-194.Sedikides, C., \& Brewer, M. B. (2001). Individual self, relational self, and collective self. Philadelphia: Psychology Press. 
Sanchez-Famoso, Valeriano, Amaia Maseda, and Txomin Lturralde. 2014. The role of internal social capital in organisational innovation. An empirical study of family firms. European Management Journal 32(6): 950 - 962.

Sharma, P., Chrisman, J.J., and J.H. Chua (2003). 'Succession Planning as Planned Behavior: some Empirical Results.' Family Business Review, 16(1), 1-16.

Skvoretz, J., Fararo, T. J. 1996. Status and participation in task groups: A dynamic network model. American Journal of Sociology, 101: 1366-1414.

Stein, B.A. (1976). 'Collective Ownership, Property Rights, and Control of the Corporation.' Journal of Economic Issues, 10(2), 298-313.

Sund, L-G. and P-O. Bjuggren (2008). 'Protection of Ownership in Family Firms, The Owner and Management Perspective.' Paper presented at the Bangkok International Forum on Indigenous Management Practice (BIFIM), Kasetsart University, Bangkok, Thailand.

Tagiuri, R. and J.A. Davis (1996). 'Bivalent attributes on the family businesses.' Family Business Review, 9 (2), 199-208.

Thomas, J. 2002. Freeing the Shackles of Family Business Ownership. Family Business Review, 15(4): $321-336$.

Tyler, Tom and Steven Blader. 2003. The Group Engagement Model: Procedural Justice, Social Identity, and Cooperative Behavior. Personality and Social Psychology Review. 7(4): 349 361.

Ucbasaran, D., Westhead, P., Wright, M., (2001). The focus of entrepreneurial research: contextual and process issues. Entrepreneurship Theory and Practice, 25(4), 57-80.

De Visscher, F.M., Aronoff, C. E., and J.L. Ward (1995).' Financing Transitions; Managing Capital and Liquidity in the Family Business.' Marietta, GA: Business Owner resource.

Ward J.L. (2001). 'Developing Effective Ownership in the Family Controlled Business.' National Association of Corporate Directors. 25(7)

Ward, J.L. (1997). 'Growing the family business: Special challenges and best practices.' Family Business Review, 10(4), 323 - 337. 
Westhead, P., Ucbasaran, D., and M. Wright (2005). 'Decisions, Actions, and Performance: Do Novice, Serial, and Portfolio Entrepreneurs Differ?’ Journal of Small Business Management, 43(4), 393-417.

White, J.M. (1991). 'Dynamics of family development: The theory of family development.' New York: Guilford

Wilson, Nick, Mike Wright, Louise Scholes. 2013. Family Business Survival and the Role of Boards. Entrepreneurship Theory and Practice 37(6): 1369 - 1389. 
Table 1.

The benefits of controlling the business and its resources in family business groups

- ability to exercise control and power over the owned businesses

- ability to transfer resources between the businesses

- ability to create internal financing instruments

The benefits of including outside investors to the distinct businesses in the group

- ability to invite outside investors to the distinct businesses in the group, while withholding the control of the group

- ability to add and exclude distinct businesses in the group, making the group strategy and structure very flexible

The benefit of operating on the levels of collective ownership and individual ownership

- ability to invite family members in the ownership of the whole group or distinct businesses

Table 2.

Social

- Social recognition

- Status

Family cohesion

- Belonging to bus.Family

- Social ties between fam mem

Individual goals

- Having a place for personal 'hobbies'

- Achievement motive

Continuity \& security

- Bus. Continuity

- Tradition continuity 